\title{
Tail Bifurcation in a Desert Lidless Skink (Ablepharus deserti) from Kyrgyzstan
}

Daniel Jablonski

Department of Zoology, Comenius University in Bratislava, Mlynská dolina, Ilkovičova 6, 84215 Bratislava, Slovakia (daniel.jablonski@balcanica.cz)

$T_{1}$ The Desert Lidless Skink (Ablepharus deserti Strauch 1868) is one of ten currently recognized species in the poorly known genus Ablepharus (family Eugongylidae; Hedges 2014), which occur collectively from central Europe and the Middle East to central Asia and northwestern India (Sindaco and Jeremčenko 2008). The Desert Lidless Skink is a small, ground-dwelling, diurnally active lizard distributed in Turkmenistan, Uzbekistan, southeastern Tajikistan, and southern and southeastern Kazakhstan and Kyrgyzstan. This species is relatively common, and it is ecologically plastic with the ability to survive in various habitats. Jeremčenko and Sčerbak (1986) presented additional information about morphology, distribution, and general biology.

On 5 May 2015, I found an adult female $A$. deserti basking in grassy habitat to the east of Jalal-Abad, Kyrgyzstan $\left(40.93748^{\circ} \mathrm{N}, 73.03702^{\circ} \mathrm{E}\right.$, WGS84, $956 \mathrm{~m}$ elev.; Fig. 1A) with a tail bifurcated posteriorly with the new segment the same length as the original tail $(-18 \mathrm{~mm})$. Total length of the individual was $90 \mathrm{~mm}$ (SVL $46 \mathrm{~mm}$ ), the tail measured 44 $\mathrm{mm}$. Based on pattern, shape, and scalation, the left bifurcation appeared to be original (Fig. 1B). The lizard was in good condition without other deformities or injuries. The presence of a double tail does not seem to have affected its welfare. As far as I know, no other previously observed cases of tail bifurcation have been reported for this genus or species. None of the other 30 adults I observed and examined at that locality on the same day had regenerated tails. The lizard with the double tail was not collected and preserved.

Tail bifurcation and related malformations occur in species that exhibit tail autotomy (some salamanders and lizards) and are relatively common (Smith 1946). Reports of this phenomenon for many species of lizards have been published (e.g., Martins et al. 2013), including species in the family Scincidae, to which lizards in the family Eugongylidae were previously assigned (Hedges 2014). Vrcibradic and Niemeyer (2013) reported the frequency of tail bifurcation as a consequence of regeneration in natural populations of two species of the genus Mabuya to be $1.7 \%$ (3 of 178 specimens) and $1.2 \%$ (1/83), respectively. In skinks (Scincidae sensu lato),
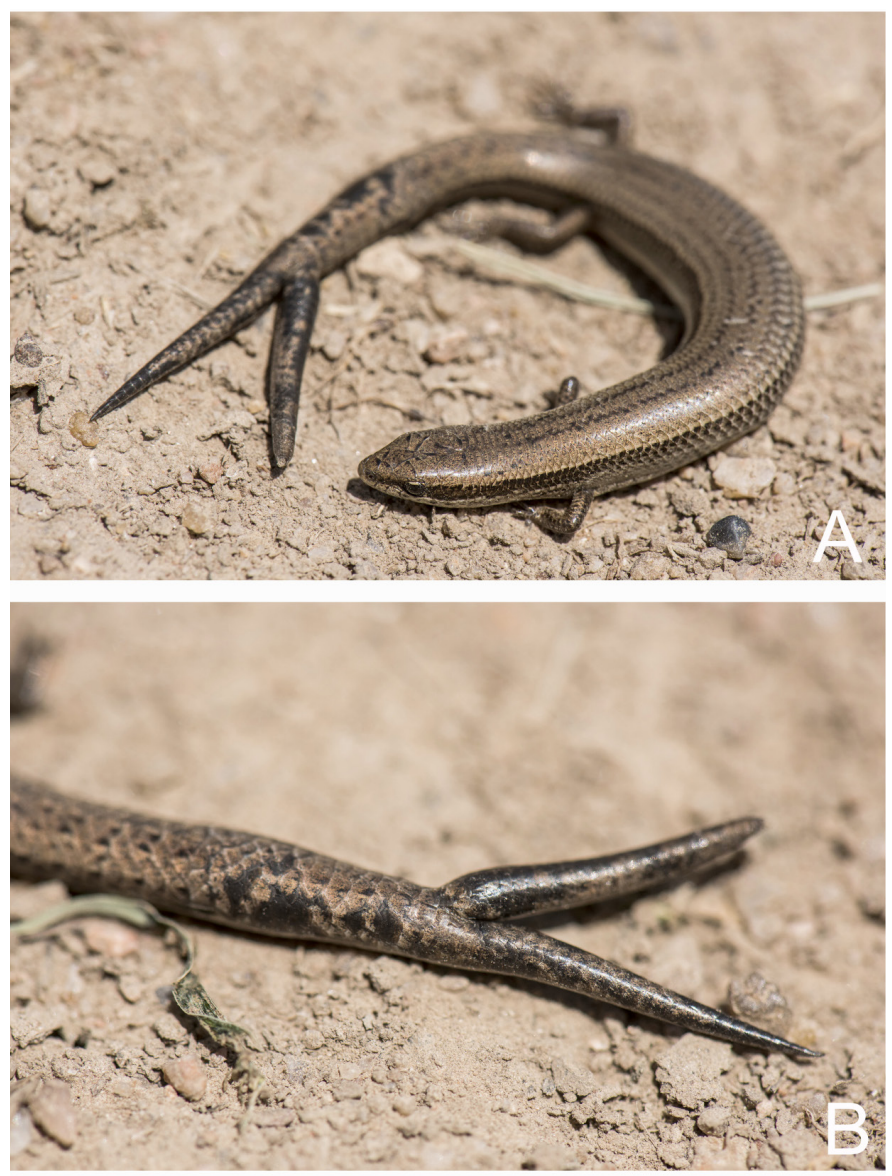

Fig. 1. An adult female Desert Lidless Skink (Ablepharus deserti) from the vicinity of Jalal-Abad (Kyrgyzstan) with a bifurcated tail (A); close-up of the tail of the same individual (B). Photographs by the author.

tail bifurcation has been recorded in the genera Eutropis, Liopholis, Mabuya, Plestiodon, and Trachylepis (e.g., Brindley 1898; Hickman 1960; Mitchell et al. 2012; Vrcibradic and Niemeyer 2013 and literature therein). However, detailed data regarding frequencies of occurrence are not available.

\section{Literature Cited}

Brindley, H.H. 1898. Some cases of caudal abnormality in Mabuya carinata and other lizards. Journal of the Bombay Natural History Society 11: 680-689. 
Hedges, S.B. 2014. The high-level classification of skinks (Reptilia, Squamata, Scincomorpha). Zootaxa 3756: 317-338.

Hickman, J.L. 1960. Observations on the skink lizard Egernia whitii (Lacépède). Papers of the Proceedings of the Royal Society of Tasmania 94: 111-118.

Jeremčenko, V.K. and N.N. Sčerbak. 1986. Ablepharidnye jashchritsy fauni SSSR $i$ soprede'nykh stran. Akademia Nauk Kirgiskoi S.S.R. Izdate'stvo Ilim, Frunze.

Martins, R.L., P.G. Peixoto, P.H.M. Fonseca, A.G. Martinelli, W.R. Silva, and A. Pelli. 2013. Abnormality in the tail of the collated lizard Tropidurus gr. torquatus (Iguania, Tropiduridae) from Uberaba City, Minas Gerais State, Brazil. Herpetology Notes 6: 369-371.
Mitchell, J.C., W. McDaniel, and J. McDaniel. 2012. Plestiodon inexpectatus (Southwestern Five-lined Skink). Bifurcation. Herpetological Review 43: 650

Sindaco, R. and V.K. Jeremčenko. 2008. The Reptiles of the Western Palearctic. 1. Annotated Checklist and Distributional Atlas of the Turtles, Crocodiles, Amphisbaenians and Lizards of Europe, North Africa, Middle East and Central Asia. Edizioni Belvedere, Latina, Italy.

Smith, H.M. 1946. Handbook of Lizards of the United States and Canada. Cornell University Press, Ithaca, New York.

Vrcibradic, D. and J. Niemeyer. 2013. Mabuya frenata, M. macrorhyncha. Tail bifurcation. Herpetological Review 44: 510-511. 